\title{
Governance and Poverty: The Governance Crisis of The Local Government
}

\author{
Gregorius Sahdan ${ }^{1}$ \\ \{gsahdan@yahoo.com ${ }^{1}$ \} \\ STPMD "APMD" Yogyakarta ${ }^{1}$
}

\begin{abstract}
This paper departs from the problem that poverty and corruption are still the biggest problems in the governance of local government in Indonesia. Since the reformation in 1998, the government has carried out various agendas to encourage the transformation of local governance both through changes in institutional models of local governance from institutional models that are rich in poor structure functions to a more streamlined institutional model. Local governments also through legislation products on local government, have been encouraged to carry out bureaucratic reform and even the Permenpan No.11 of 2015 concerning the Road Map of Bureaucratic Reform has explicitly had a road map for bureaucratic reform as a key agenda for improving local governance, but so far the results have not had an impact on reducing corruption which impedes the realization of public welfare. Poverty remains a ghost that surrounds the administration of local government in Indonesia. The question posed in this paper is "how are local governance in Indonesia? To what extent does the influence of local governance in Indonesia affect poverty and corruption reduction? The results of the study show that local governance has not been fully implemented in accordance with the 1998 reform agenda, especially in combating corruption and poverty. These findings indicate that our local governance is still facing a crisis, has not been able to eradicate poverty and corruption.
\end{abstract}

Keywords: Governance, Governance Crisis, Local Government, Poverty

\section{Introduction}

Decentralization having been carried out since 2001 and local leaders election (Pilkada) which have been carried out since 2005 do not always contribute to the better initiatives of the local governance. In many regions, decentralization and Pilkada find obstacles that arise from serious internal and external problems [1], [2]. In the local government, decentralization deals with the corruption that hampers the efforts to eradicate poverty. From the external factors, decentralization is related to the indecisiveness of the central government to divide and formulate clear and detailed authority regarding the basic functions of the central government in encouraging governance of the local government, especially how the control and coordination between the central government and the local governments work.

Control and coordination are the instruments that enable the central government to direct and encourage development progress, local economic growth and ensure that the local governance works well. Jakarta's frustration with the poor governance of the local government 
considered threats by the Coordinating Minister for Political, Legal, and Security Affairs, Luhut Binsar Panjaitan, towards Papua Local Government, should not have occurred if the central government had strengthened the control and coordination properly . Nevertheless, Jakarta's frustration is a big framework for the weakness of Jakarta's power in dealing with the local government. The only key to control the authority of the central government is to control the transfer of the budget from the state to the regional budget, especially in the regions which are poorly managed. On the other hand, the central government can also cut the authority chain and encourage the transformation of governance at local government based on the strengths and initiatives of the government, communities and business groups in the region. This is a trigger for the regions to perform better governance.

In the local democracy which is carried out in the form of direct local elections (simultaneously in 2015 in 269 regions), it does not always produce passionate leaders who are able to carry out the mandate. Since the last 11 years (2004-2015), based on the records and publications of the Corruption Eradication Commission (KPK), there were around 56 local leaders (Provinces and Districts / Cities) imprisoned . In average, they were ensnared by corruption cases committed a deviation of authority, both in budget and in asset governance, and in licensing. However, there were also local leaders caught in bribery cases. The involvement of the local leaders in corruption cases becomes a popular phenomenon in the wider community, especially on how the practice of power abuse is firmly rooted in government, including that in democratically elected governments. For the central government, this case is a bad precedent for the commitment to realize good governance, starting from the regions. The followings are some local leaders imprisoned due to corruption cases. See table.

Table 1

\begin{tabular}{|c|c|c|}
\hline No & Local Leaders & Case \\
\hline 1 & $\begin{array}{l}\text { Abdullah Puteh-Governor of } \\
\text { NAD }\end{array}$ & $\begin{array}{l}\text { Procurement of the NAD Government-owned } \\
\text { Mi-2 Helicopter aircraft }\end{array}$ \\
\hline 2 & $\begin{array}{l}\text { Suwarna Abdul Fatah, Governor } \\
\text { of East Borneo }\end{array}$ & $\begin{array}{l}\text { The implementation of the one-million-hectare } \\
\text { oil palm plantation development program in East } \\
\text { Borneo followed by the issuance of timber } \\
\text { utilization permits in } 1999-2002\end{array}$ \\
\hline 3 & $\begin{array}{l}\text { Abubakar Ahmad, Regent of } \\
\text { Dompu }\end{array}$ & $\begin{array}{l}\text { Expenditures or use of funds not in accordance } \\
\text { with the allocation of funds for unexpected } \\
\text { Dompu District Budget 2003-2005 }\end{array}$ \\
\hline 4 & $\begin{array}{l}\text { Sjahril Darham-Governor of } \\
\text { South Borneo }\end{array}$ & $\begin{array}{l}\text { Use of funds not in accordance with the } \\
\text { designation of the local head post budget in South } \\
\text { Borneo for 2001-2004 }\end{array}$ \\
\hline 5 & $\begin{array}{l}\text { Hendy Boedoro, Regent of } \\
\text { Kendal }\end{array}$ & $\begin{array}{l}\text { Utilization of authority for the use of APBD in } \\
2003 \text {, unexpected funding for the general } \\
\text { allocation fund and the local loan fund in Kendal } \\
\text { that are not in accordance with the applicable } \\
\text { provisions }\end{array}$ \\
\hline 6 & $\begin{array}{l}\text { Syaukani HR - Regent of Kutai } \\
\text { Kertanegara }\end{array}$ & $\begin{array}{l}\text { The implementation of the airport development } \\
\text { project in Samarinda Kutai Kertanegara East } \\
\text { Borneo in 2003-2004 }\end{array}$ \\
\hline 7 & $\begin{array}{l}\text { Baso Amiruddin Maula-Mayor of } \\
\text { Makassar }\end{array}$ & $\begin{array}{l}\text { Procurement project of Tohatsu fire extinguisher } \\
\text { Type V-80-ASM in Makassar Government } \\
\text { APBD in } 2003 \text { and } 2004\end{array}$ \\
\hline 8 & Abbdillah-Mayor of Medan & $\begin{array}{l}\text { Procurement project of Morita fire extinguishers } \\
\text { in Medan Government APBD in } 2005 \text { and in } \\
2002-2006\end{array}$ \\
\hline
\end{tabular}




\begin{tabular}{|c|c|c|}
\hline 9 & Ramli-Deputy Mayor of Medan & $\begin{array}{l}\text { Procurement project of Morita firefighting cars in } \\
\text { Medan APBD } 2005\end{array}$ \\
\hline 10 & $\begin{array}{l}\text { Tengku Azmun Jaafar-Regent of } \\
\text { Pelalawan }\end{array}$ & $\begin{array}{l}\text { Utilization of Licensing in the issuance of HHK- } \\
\text { HT /IPK IUP 2001-2006 in Pelalawan which is } \\
\text { not in accordance with the provisions }\end{array}$ \\
\hline 11 & Agus Supriadi, Regent of Garut & Misuse of Garut APBD in 2004-2007 \\
\hline 12 & $\begin{array}{l}\text { Vonnie A. Panambunan - Regent } \\
\text { of North Minahasa }\end{array}$ & Utilization of Minahasa APBD \\
\hline 13 & Iskandar-Regent of West Lombok & $\begin{array}{l}\text { Ransacked land and the former building of West } \\
\text { Lombok Regent's office in } 2004\end{array}$ \\
\hline 14 & $\begin{array}{l}\text { Deny Setiawan - Former } \\
\text { Governor of West Java }\end{array}$ & $\begin{array}{l}\text { Procurement of fire trucks, ambulances, stoom } \\
\text { walls and dump trucks by the Government of } \\
\text { West Java } 2003\end{array}$ \\
\hline 15 & $\begin{array}{l}\text { Armen Desky-Regent of } \\
\text { Southeast Aceh }\end{array}$ & $\begin{array}{l}\text { Governance of Southeast Aceh APBD in 2004- } \\
2006\end{array}$ \\
\hline 16 & $\begin{array}{l}\text { Jimmy Rimba Rogi-Regent of } \\
\text { Manado }\end{array}$ & Disbursing Manado APBD in 2006 \\
\hline 17 & $\begin{array}{l}\text { Samsuri Aspar-Deputy Regent of } \\
\text { Kutai Kertanegara }\end{array}$ & $\begin{array}{l}\text { Utilization of social assistance budget in Kutai } \\
\text { Kertanegara in } 2005\end{array}$ \\
\hline 18 & of Situbondo & Utilization of Situbondo APBD in 2005-2007 \\
\hline 19 & $\begin{array}{l}\text { Syahriial Oesman - Former } \\
\text { Governor of South Sumatra }\end{array}$ & $\begin{array}{l}\text { Involvement in giving funds to civil servants or } \\
\text { state administrators in relation to the process of } \\
\text { requesting the conversion of protected forests of } \\
\text { Air Telang Beach in South Sumatra }\end{array}$ \\
\hline 20 & $\begin{array}{l}\text { Jules F. Warikar-Regent of } \\
\text { Supiori }\end{array}$ & $\begin{array}{l}\text { Central Supiori market development activities, } \\
\text { main terminal, official echelon housing and } \\
\text { Supiori central market renovation for Bank Papua } \\
\text { branch offices using Supiori APBD in 2006-2008 }\end{array}$ \\
\hline 21 & $\begin{array}{l}\text { Hamid Rizal-Former regent of } \\
\text { Natuna }\end{array}$ & $\begin{array}{l}\text { The utilization of Natuna APBD in } 2004 \text { not in } \\
\text { accordance with the allocation and cash } \\
\text { disbursement without complete and valid } \\
\text { evidence }\end{array}$ \\
\hline 22 & $\begin{array}{l}\text { H. Daeng Rusnadi- Regent of } \\
\text { Natuna }\end{array}$ & $\begin{array}{l}\text { Misuse of APBD in } 2004 \text { not in accordance with } \\
\text { its allotment and incomplete and legal cash } \\
\text { disbursements }\end{array}$ \\
\hline 23 & Arwin AS-Regent of Siak & $\begin{array}{l}\text { Issuance of business licenses for utilization of } \\
\text { timber products in } 2001-2003\end{array}$ \\
\hline 24 & $\begin{array}{l}\text { Ismeth Abdullah-Governor of } \\
\text { Riau Islands }\end{array}$ & Procurement of Morita firefighters in 2004-2005 \\
\hline 25 & Indra Kusuma-Regent of Brebes & $\begin{array}{l}\text { Land acquisition for markets in Brebes district } \\
\text { government in } 2003\end{array}$ \\
\hline 26 & $\begin{array}{l}\text { Yusak Yaluuwo-Regent of Boven } \\
\text { Digoel }\end{array}$ & Utilization of APBD and OTSUS 2006-2007 \\
\hline 27 & $\begin{array}{l}\text { Syamsul Arifin, Governor of } \\
\text { North Sumatra }\end{array}$ & $\begin{array}{l}\text { Utilization and governance of local treasury in } \\
\text { Langkat APBD in 2000-2007 }\end{array}$ \\
\hline 28 & $\begin{array}{l}\text { Jefferson Sooleiman Montesqieu } \\
\text { Rumajar-Mayor of Tomohon }\end{array}$ & $\begin{array}{l}\text { Misuse of Tomohon Government APBD in 2006- } \\
2008\end{array}$ \\
\hline 29 & $\begin{array}{l}\text { Mohchtar Mohamad-Mayor of } \\
\text { Bekasi }\end{array}$ & $\begin{array}{l}\text { Governance and financial accountability of } \\
\text { Bekasi APBD in } 2010\end{array}$ \\
\hline 30 & $\begin{array}{l}\text { Binahati B. Baeha - Regent of } \\
\text { Nias }\end{array}$ & Nias natural disaster governance funds in 2007 \\
\hline 31 & $\begin{array}{l}\text { Robert Edison Siahaan - Former } \\
\text { Mayor of Pematang Siantar }\end{array}$ & $\begin{array}{l}\text { Regional secretariat social assistance governance } \\
\text { APBD in } 2007\end{array}$ \\
\hline
\end{tabular}




\begin{tabular}{|c|c|c|}
\hline 32 & $\begin{array}{l}\text { Fahuwusa Laila-Regent of South } \\
\text { Nias }\end{array}$ & Rewards to state employees or state officials \\
\hline 33 & $\begin{array}{l}\text { Murman Effendi-Regent of } \\
\text { Seluma }\end{array}$ & Promises to give rewards to civil servants \\
\hline 34 & $\begin{array}{l}\text { Soemarmo Hadi Saputro-Mayor } \\
\text { of Semarang }\end{array}$ & $\begin{array}{l}\text { Rewards to the civil servants and Semarang } \\
\text { secretary }\end{array}$ \\
\hline 35 & Amran Batalipu-Regent of Buol & $\begin{array}{l}\text { Receiving rewards regarding the governance of } \\
\text { HGU plantations on behalf of PT. Cipta Cakra } \\
\text { Murdaya and PT. Hardaya Inti Plantation, Central } \\
\text { Sulawesi }\end{array}$ \\
\hline 36 & $\begin{array}{l}\text { Muhammad Hidayat Batubara - } \\
\text { Regent of Mandaling Natal }\end{array}$ & $\begin{array}{l}\text { Rewards to civil servants using Local Aid Fund } \\
\text { (DBD) in } 2013\end{array}$ \\
\hline 37 & Dada Rosada-Mayor of Bandung & Rewards from Bandung Social Assistance fund \\
\hline 38 & $\begin{array}{l}\text { Hambit Binti, Regent of Gunung } \\
\text { Mas }\end{array}$ & $\begin{array}{l}\text { Rewards to judges in order to influence the } \\
\text { decision of the case for the dispute over the } \\
\text { Pilkada in Gunung Mas, Central Borneo }\end{array}$ \\
\hline 39 & Rusli Zainal, Governor of Riau & $\begin{array}{l}\text { Ratification of the work plan for plantation forest } \\
\text { product utilization }\end{array}$ \\
\hline 40 & $\begin{array}{l}\text { Ratu Atut Chosiyah-Governor of } \\
\text { Banten }\end{array}$ & $\begin{array}{l}\text { Rewards to judges in connection with the dispute } \\
\text { over Pilkada in Lebak Banten in } 2013 \text { at the } \\
\text { Constitutional Court }\end{array}$ \\
\hline 41 & Ikmal Jaya-Mayor of Tegal & $\begin{array}{l}\text { Implementation of land swap between Tegal } \\
\text { government and private sector in } 2012\end{array}$ \\
\hline 42 & $\begin{array}{l}\text { Ilham Arief Sirajuddin-Mayor of } \\
\text { Makassar }\end{array}$ & $\begin{array}{l}\text { Collaborative work of rehabilitation, governance } \\
\text { and transfer of water treatment plants between } \\
\text { Makassar PDAM and private sectors for the } \\
\text { period of 2006-2011 }\end{array}$ \\
\hline 43 & Rachmat Yasin - Regent of Bogor & $\begin{array}{l}\text { Receiving gifts or promises related to giving } \\
\text { recommendations for exchanging forest areas in } \\
\text { Bogor on behalf of PT. Bukit Jonggol Asri }\end{array}$ \\
\hline 44 & $\begin{array}{l}\text { ton-Mayor of } \\
\mathrm{g}\end{array}$ & $\begin{array}{l}\text { Rewards to judges to revise the court's decision in } \\
\text { the Constitutional Court in } 2013\end{array}$ \\
\hline 45 & $\begin{array}{l}\text { Yesaya Sombuk-Regent of Biak } \\
\text { Numfor }\end{array}$ & $\begin{array}{l}\text { Civil servants at the PDT ministry for the } \\
\text { TALUD project in Biak Numfor, Papua }\end{array}$ \\
\hline 46 & Ade Swara-Regent of Karawang & $\begin{array}{l}\text { SPPR approval on behalf of PT. Tattar Kertabumi } \\
\text { in Karawang }\end{array}$ \\
\hline 47 & $\begin{array}{l}\text { aran Situmeang-Regent } \\
\text { I Tapanuli }\end{array}$ & $\begin{array}{l}\text { Rewards to a judge named M. Akil Mochtar in } \\
\text { the } 2011 \text { on the case of Pilkada }\end{array}$ \\
\hline 48 & Amir Hamzah, Regent of Lebak & $\begin{array}{l}\text { Rewards to influence the Constitutional Court's } \\
\text { decision in } 2013\end{array}$ \\
\hline 49 & $\begin{array}{l}\text { Zaini Arony, Regent of West } \\
\text { Lombok }\end{array}$ & $\begin{array}{l}\text { Obtaining licenses related to the development of } \\
\text { tourist areas in West Lombok 2010-2012 }\end{array}$ \\
\hline 50 & Fuad Amin-Regent of Bangkalan & $\begin{array}{l}\text { Receiving rewards related to the sale and } \\
\text { purchase of natural gas for power plants in Gersik } \\
\text { and East Gili Bangkalan Madura, East Java }\end{array}$ \\
\hline 51 & Barnabas Suebu, Governor of & Detail Engineering Design (DED) \\
\hline & Papua & $\begin{array}{l}\text { Memberamo River Hydroelectric Power Plant } \\
\text { and Urumuka River in 2009-2010 }\end{array}$ \\
\hline 52 & Annas Maamun-Governor of Riau & $\begin{array}{l}\text { Civil servants related to the submission of } \\
\text { revisions to the transfer of forest functions in } \\
\text { Riau to the Ministry of Forestry in } 2014\end{array}$ \\
\hline 53 & $\begin{array}{l}\text { Marthen Dira Tome-Regent of } \\
\text { Abu Raijua }\end{array}$ & $\begin{array}{l}\text { Misuse of the authority in using the school } \\
\text { outdoor education funds in East Nusa Tenggara }\end{array}$ \\
\hline
\end{tabular}




\begin{tabular}{cll}
\hline 54 & $\begin{array}{l}\text { Budi Anton Aljufri, Regent of } \\
\text { Empat Lawang }\end{array}$ & $\begin{array}{l}\text { Education and Culture Sub-Department in 2007 } \\
\text { Rewards to judge to influence decisions related to } \\
\text { disputes in Pilkada 2013 }\end{array}$ \\
Rusli Sibua-Regent of Moroati & $\begin{array}{l}\text { Rewards to judge to influence the Constitutional } \\
\text { Court's decision on the case of Pilkada dispute in }\end{array}$ \\
& Island & $\begin{array}{l}2011 \\
\text { Gatot Pujo Nugroho-Governor of }\end{array}$ \\
North Sumatra & $\begin{array}{l}\text { Rewards to Medan State Administrative Court } \\
\text { judges and clerks related to social assistance } \\
\text { funds and subordinate regional assistance (BDB), } \\
\text { school operational assistance (BOS) and the } \\
\text { detention of disbursement of profit sharing funds } \\
\text { (DBH) conducted by the governor of North } \\
\text { Sumatra at the PTUN. }\end{array}$ \\
\hline
\end{tabular}

Source: Several sources.

The data in the local governance in the last 11 years, especially when the decentralization in 2001 and the local leaders election have been held since 2005, shows that corruption is a major obstacle to the governance of local government in realizing the welfare of local communities. The types of corruption appear to be more various and involve many actors. Corruption networks are not only created within the government but also spread to the judiciary as a law enforcement institution and it even involves businessmen in the private sectors.

\section{Method}

The method used in this research is a descriptive qualitative method that attempts to describe local governance in Indonesia based on data sources from documents, books, media news and journals that are used as material to strengthen analysis. The analysis technique used is interpretive analysis by trying to provide interpretation in accordance with the research interests and based on existing data.

\section{Result and Discussion}

\subsection{Decentralization, Local Democracy and Corruption}

States that corruption is a deviant behavior of state officials carried out to obtain personal benefits by violating the law or legislation. Regardless of the types of corruption that occur in the regions, corruption is clearly an example of poor governance practices. Corruption causes local government to get difficulty optimizing the use of Regional Budgets (APBD) in realizing community welfare. Jacob Chikuhwa [3] in his book "The crisis of governance: Zimbawe" states that corruption is not only a proof of poor governance but also seen as the biggest barrier for people to access the regional budgets to meet the basic needs of the citizens. The central government, according to Chikuhwa, is supposed to provide access to the citizens, especially the poor to get the regional budgets. However, corruption in the government clearly makes it troublesome. Studies conducted by various institutions, including UNDP in 2011, indicate that decentralization has not fully brought benefits to the strengthening and development of the governance of the local government in a tangible goal. Decentralization still gets problems in the local government and in its relations with the central government. The following table gives an overview of the problem in both sides. See the following table.

Table 2. Decentralization Program in Indonesia 


\begin{tabular}{|c|c|}
\hline No & Local Program \\
\hline 01 & $\begin{array}{l}\text { Decentralization produces local leaders who } \\
\text { loot local government programs. The programs } \\
\text { are used to maximize people's welfare, but are } \\
\text { looted by government elites who cooperate with } \\
\text { business groups. }\end{array}$ \\
\hline 02 & $\begin{array}{l}\text { Local governments exploit local resources to } \\
\text { restore expenditures in local elections - } \\
\text { Problematic mining permits becomes a crucial } \\
\text { issue of intergovernmental relations with local } \\
\text { communities }\end{array}$ \\
\hline
\end{tabular}

03 The local government bureaucracy takes APBD more than the budget for the poor. In some regions, even the bureaucratic spending budget reaches more than $50 \%$ compared to the budget for the poor.

04 The local leaders hold an enormous authority as a consequence of Pilkada, while with such an authority, the inclusion and expansion of local democracy in the form of substantive access and public participation in government policies are still very closed. Some regions with very limited democratic inclusion are Maluku, Papua and West and East Nusa Tenggara. In those regions, local leadership needs to be encouraged to strengthen the inclusion of local democracy.

05 Local communities in some regions with leadership that is less visionary, have apathy and do not even care about the governance of local government. They tend to assume that the governance of the local government is not part of their responsibilities.
Problems related to the central government The central government has not got the instruments to control the implementation of local government programs through Pilkada.

Local resource governance permits granted by the central government to local governments are not properly controlled in their implementation, so the regions freely manage resources that lack economic benefits to local communities.

The central government bureaucracy reforms agenda created by the Ministry of Administrative and Bureaucratic Reform does not solve the bureaucratic problems in the regions. The bureaucracy in the region tends to waste the public budget for internal bureaucracy.

The central government gets difficulty in controlling the local leaders because they consider that they come from a different political party support base. The central government also has less power to consolidate local governments, especially in mobilizing local governments to go hand in hand with central government policies.

The central government has not provided access and opportunity to the public to be a subject in the governance of the local government. The central government policy tends to limit the involvement of local communities in the governance, for instance the case of problematic mining, local people are subject to criminal law for their activities against government policies.

\section{Source: Several sources}

Decentralization and local leaders election is supposed to encourage better governance, but in fact, in some decentralized and local democracies it is such a hardship to achieve prosperity. It happens because the principles of good governance are often ignored and considerably not based on local culture. Disregarding the principles of good governance is sometimes the reason and chance for the people in the local government to commit corruption and ignore their responsibility to prosper the community. Until today, wherever decentralization and local democracy become the basis of local government governance, there are still many areas that have fallen into poverty due to the corruption in the local government governance. Pilkada which is a milestone in strengthening local democracy, in the most crucial aspect precisely causes corrupt and irresponsible leadership to work improperly in taking care of the 
community. The chosen government through Pilkada still causes problems as Archon Fung [4] states, "Government is a problem not solution". The study of Indonesian Power for Democracy (IPD) 2010 and 2015 shows several things that become obstacles why Pilkada have not met the solution to strengthening local democracy:

1) Political parties have not carried out the function of recruitment and political regeneration properly, so that they are mostly used as "cattle traders", meaning they are more often used as "riding horses", rather than as a locator of local democracy;

2) Money politics still plays a big role in Pilkada which then results in leadership that is oriented to money or what is often referred to the government driven by money, not one that makes money. In this case, candidates who compete in the elections are mostly motivated to get back the amount of the money they spend in the elections;

3) Voters' participation has not been fully based on the spirit of volunteerism, but rather driven by the money they get from the candidates. It utilizes the community and has not fully made the community as a subject in regional development;

4) There are many candidates who compete in Pilkada considered poor in their vision and mission in building the region. The main pressure of their campaign is how to drive economic growth by bringing in investors. Investment is considered a helper that will bring the region to accelerate development and economic growth. As a result, many candidates compete in direct and simultaneous local elections have great dependence on mining companies both domestically and internationally. Whereas the development of the area begins with building the quality of human resources to reduce the number of human resources from other regions. Direct and simultaneous local elections provide a big chance for the exploitation of natural resources due to the victory of candidates who are poor in their vision and mission in developing the region;

5) Local leaders who are elected through direct and simultaneous local elections are still doubtful about their capacity to manage and develop local resources into potential resources for regional development. Most regional budgets still rely on general allocation funds sourced from the state budget. While the Regional Original Revenue (PAD), has not been fully boosted to increase the source of budget and regional development costs. The study conducted by Pipit Budiarti on the Influence of Regional Original Revenue (PAD) and General Allocation Funds (DAU) (2014) shows that transfers from the central government to local governments are still relatively high at around $72-86 \%$ in supporting regional government spending and operations. In some areas such as Yogyakarta, East Nusa Tenggara, West Nusa Tenggara and other poor areas such as Maluku and Papua, DAU has a very central role in supporting regional development. Whereas in developed countries such as the United States, the composition of the APBD only around 40\% comes from the central government and the rest is the source of income derived from PAD. Thus it can be said that APBD structure, which is largely supported by $\mathrm{PAD}$, is a better keyword for local government governance. The local government can manage APBD more freely to prioritize poverty eradication and strengthen human resources in the region.

\subsection{Decentralization and Competitiveness}

On the other hand, decentralization has also not succeeded in maximizing the effective, efficient and competitive governance of local government. It also causes Indonesia's competitiveness at the global level not to be able to keep pace with the other developed countries and even lag far behind countries in ASEAN. Based on the World Economic Forum 
(WEF) survey, Indonesia's global competitiveness index in 2012 was no better from other countries in ASEAN. If in 2011 it took the 46th rank, in 2012 it took the 50th rank out of 144 countries (see table).

Table 3. Competitiveness Index of ASEAN Countries at the Global level

\begin{tabular}{llcccc}
\hline No & Country & \multicolumn{4}{c}{ Index of Competitiveness } \\
& & $2010-2011$ & $2011-2012$ & $2012-2013$ & $2013-2014$ \\
\hline 01 & Singapore & 3 & 2 & 2 & 2 \\
02 & Malaysia & 26 & 21 & 25 & 20 \\
03 & Brunei & 28 & 28 & 28 & - \\
04 & Thailand & 38 & 39 & 38 & 31 \\
05 & Indonesia & 44 & 46 & 50 & 34 \\
06 & Filipina & 85 & 75 & 65 & - \\
\hline
\end{tabular}

Table: taken from various sources

In 2014-2015, Indonesia's competitiveness index had slightly increased to rank 34 of 144 countries. The WEF defines competitiveness as a collection of institutions, policies and factors that determine the level of state productivity. Every year WEE publishes country ranking reports using the Global Competitiveness Index (GCI). GCI is a measure of the competitiveness of each country by using 126 indicators grouped into 12 namely; institutions, infrastructure, macroeconomic environment, basic education and health, higher education and training, goods market efficiency, labor market efficiency, financial market development, readiness of technology, market size, business sophistication and innovation. Five countries with high competitiveness are Switzerland, Singapore, the United States, Finland and Germany. There were five things that made Indonesia progress a little in 2014-2015, including market size (the 15th rank), innovation (the 31st rank), macroeconomic environment (the 34th rank), business sophistication (the 34th rank) and financial market development. The rating shows that Indonesia has competitiveness in the economic field. While the five low indicators are; labor market efficiency (the 110th rank), readiness of technology (the 77th rank), basic education and health (the 74th rank), infrastructure (the 56th rank) and institutional (the 53rd rank) (WEE, 30 December 2014).

Those five indicators reflect that Indonesia needs to improve national competitiveness starting from regions (including villages). Competitiveness related to basic education, health, infrastructure and institutions is the tangible condition of poor regions in Indonesia. Accordingly, it can be said that decentralization has not resulted in better local governance and even been able to mobilize local potential to improve the welfare of the community. One of the local potentials that are often overlooked by the local governments is the development of human resources. Since 2011, the road map on resource development human power remains a jargon of each local government and has not been realized. This is of course very influential on the ability of Indonesian workers, both in domestic and in international markets. In the international market, Indonesian workers are still not paid like workforce with high discipline and skills. Compared with other developed countries such as Germany, America, and even Singapore, South Korea and Japan, Indonesian workers have not become professional labor. The problem is absolutely not only related to the commitment and policies of the central government that are pro-regional, but also the problems of the regions that are less concerned with human resource development. The following data is clear enough to illustrate that in the past five years, the development of human resources through education was not a commitment and strategic step of the regional government. Nonetheless, it should also be recognized that 
when compared with the previous five years (2003-2008), human development at the local level experienced significant development, at least experiencing better development. See the following table.

Table 4. Human Development Index of Indonesian Government

\begin{tabular}{|c|c|c|c|c|c|c|}
\hline No & Province & 2009 & 2010 & 2011 & 2012 & 2013 \\
\hline 1 & Aceh & 71.31 & 71.7 & 72.16 & 72.51 & 73.05 \\
\hline 2 & North Sumatera & 73.8 & 74.19 & 74.65 & 75.13 & 75.55 \\
\hline 3 & West Sumatera & 73.44 & 73.78 & 74.28 & 74.7 & 75.01 \\
\hline 4 & Riau & 75.6 & 76.07 & 76.53 & 76.9 & 77.25 \\
\hline 5 & Jambi & 72.45 & 72.74 & 73.3 & 73.78 & 74.35 \\
\hline 6 & South Sumatera & 72.61 & 72.95 & 73.42 & 73.99 & 74.36 \\
\hline 7 & Bengkulu & 72.55 & 72.92 & 73.4 & 73.93 & 74.41 \\
\hline 8 & Lampung & 70.93 & 71.42 & 71.94 & 72.45 & 72.87 \\
\hline 9 & Bangka Belitung Islands & 72.55 & 72.86 & 73.37 & 73.78 & 74.29 \\
\hline 10 & Riau Islands & 74.54 & 75.07 & 75.78 & 76.2 & 76.56 \\
\hline 11 & Jakarta & 77.36 & 77.6 & 77.97 & 78.33 & 78.59 \\
\hline 12 & West Java & 71.64 & 72.29 & 72.73 & 73.11 & 73.58 \\
\hline 13 & Central Java & 72.1 & 72.49 & 72.94 & 73.36 & 74.05 \\
\hline 14 & Yogyakarta & 75.23 & 75.77 & 76.32 & 76.75 & 77.37 \\
\hline 15 & East Java & 71.06 & 71.62 & 72.18 & 72.83 & 73.54 \\
\hline 16 & Banten & 70.06 & 70.48 & 70.95 & 71.49 & 71.90 \\
\hline 17 & Bali & 71.52 & 72.28 & 72.84 & 73.49 & 74.11 \\
\hline 18 & West Nusa Tenggara & 64.66 & 65.2 & 66.23 & 66.89 & 67.73 \\
\hline 19 & East Nusa Tenggara & 66.6 & 67.26 & 67.75 & 68.28 & 68.77 \\
\hline 20 & West Borneo & 68.79 & 69.15 & 69.66 & 70.31 & 70.93 \\
\hline 21 & Central Borneo & 74.36 & 74.64 & 75.06 & 75.46 & 75.68 \\
\hline 22 & South Borneo & 69.3 & 69.92 & 70.44 & 71.08 & 71.74 \\
\hline 23 & East Borneo & 75.11 & 75.56 & 76.22 & 76.71 & 77.33 \\
\hline 24 & North Borneo & - & - & - & - & 74.72 \\
\hline 25 & North Sulawesi & 75.68 & 76.09 & 76.54 & 76.95 & 77.36 \\
\hline 26 & Central Sulawesi & 70.7 & 71.14 & 71.62 & 72.14 & 72.54 \\
\hline 27 & South Sulawesi & 70.94 & 71.62 & 72.14 & 72.7 & 73.28 \\
\hline 28 & South-east Sulawesi & 69.52 & 70.00 & 70.55 & 71.05 & 71.73 \\
\hline 29 & Gorontalo & 69.79 & 70.28 & 70.82 & 71.31 & 71.77 \\
\hline 30 & West Sulawesi & 69.18 & 69.64 & 70.11 & 70.73 & 71.41 \\
\hline 31 & Maluku & 70.96 & 71.42 & 71.87 & 72.42 & 72.70 \\
\hline 31 & North Maluku & 68.63 & 69.03 & 69.47 & 69.98 & 70.63 \\
\hline
\end{tabular}




\begin{tabular}{lcccccc}
\hline 33 & West Papua & 68.58 & 69.15 & 69.65 & 70.22 & 70.62 \\
34 & Papua & 64.53 & 64.94 & 65.36 & 65.86 & 66.25 \\
National/Indonesia & 71.76 & 72.27 & 72.77 & 73.29 & 73.81 \\
\hline
\end{tabular}

Source: Results of partnership survey in 2014.

The data shows human development in each region varies. In three years, under the leadership of Basuki Tjahaja Purnama or Ahok, DKI Jakarta experienced a tremendous human development leap. In the past three years, Papua Province did not achieve significant human development. The same thing happened in West Nusa Tenggara and East Nusa Tenggara (NTT). The three regions in the last five years were also recorded as areas with high poverty rates. In NTT, Governor Frans Leburaya, who was famous for his Red Wine Program, failed to build the quality of human resources as one of the entrances to realize the prosperity and welfare of the people.

\subsection{Governance and poverty}

Poverty is one of the measuring tools to see governance practices in the region. Regions with high poverty rates can be ascertained that there are bad local governance practices. In contrast, regions with low poverty rates can be ascertained there is good governance. The followings are some of the provinces with the highest poverty rates in 2015. It shows that the expansion of provinces in Indonesia has not succeeded in becoming a way to community welfare, such as the division of Papua and South Sulawesi provinces. On the other hand, Pilkada has also not succeeded in producing good local leadership that is able to change poverty into a potential for the welfare and prosperity of the people. While in regions with abundant resources, it becomes an area with national poverty rates such as Aceh and Papua. See table.

Table 5. Provinces with the Highest Poverty Rate in Indonesia

\begin{tabular}{|c|c|c|}
\hline No & Province & Percentage of Poverty \\
\hline 01 & Papua Barat & $\begin{array}{l}36.80 \% \text { - West Papua takes the } 1^{\text {st }} \text { rank as the poorest } \\
\text { province in Indonesia. This province is a new expansion } \\
\text { province from its provincial parent of Papua. The population } \\
\text { is around } 770 \text { thousand. }\end{array}$ \\
\hline 02 & Papua & $\begin{array}{l}34.88 \% \text { - Papua takes the } 2^{\text {nd }} \text { rank as the poorest province in } \\
\text { Indonesia. The population is around } 2.9 \text { million. }\end{array}$ \\
\hline 03 & Maluku & $\begin{array}{l}27.74 \% \text {-Maluku, the capital of Ambon, takes the third rank } \\
\text { to become the poorest province in Indonesia. The population } \\
\text { is around } 1.5 \text { million. }\end{array}$ \\
\hline 04 & West Sulawesi & $\begin{array}{l}23.19 \% \text { of the Province of West Sulawesi takes the fourth } \\
\text { rank as the poorest province in Indonesia. The population is } \\
\text { around } 1.1 \text { million. }\end{array}$ \\
\hline 05 & East Nusa Tenggara & $\begin{array}{l}23.03 \% \text { - With the population of around } 4.6 \text { million, this } \\
\text { province is always ranked as the poorest province in } \\
\text { Indonesia. }\end{array}$ \\
\hline 06 & West Nusa Tenggara & $\begin{array}{c}21.55 \% \text {-Being an adjacent to East Nusa Tenggara, it has got } \\
\text { a similarity to East Nusa Tenggara, which means it is } \\
\text { considered the poorest province in Indonesia }\end{array}$ \\
\hline 07 & Aceh & $\begin{array}{c}20.98 \% \text {-Nanggroe Aceh Darussalam actually has a lot of } \\
\text { foreign exchange, but NAD is always ranked as the poorest } \\
\text { province in Indonesia. }\end{array}$ \\
\hline
\end{tabular}


The study conducted by Alonso Terne [5] shows that there is a very close correlation between governance and poverty. The practice of poor governance becomes the chance for the emergence of corrupt governance and acute poverty of local communities. One of the interventions to eradicate poverty is encouraging good governance, pro-people governance and giving a special portion of the budget to eradicate poverty [6].

Good governance is a very decisive factor in eradicating poverty. Studies conducted by UNDP show that one of the loopholes that can be performed to reduce poverty in the regions is to practice or implement good governance. The World Bank in 2006 defines good governance as an institution which is seen from several basic indicators, among others; participation, accessibility, transparency, responsiveness, effectiveness and efficiency, justice, law enforcement, accountability and conflict governance. Smeru's [6] study also presents that decentralization has brought serious changes to several aspects of the principles of good governance, but in other aspects, it is still necessary to make improvements and serious changes. The aspects include:

1) Community accessibility to government public services such as education. Smeru's study shows that most students still go to school on foot, but the number of those students decreases with the increasing levels of education. Nearly $80 \%$ of elementary students go to school on foot.

2) Community participation in government services, for example in education services. In primary school education, for example, the net enrollment rate in the past year was reported to be around $95 \%$, while in this data it was recorded only $72 \%$.

3) Access to village administration services is measured using variables related to the ease of obtaining an identity card (KTP). Around $61 \%$ of family members have got KTP. The average time needed to get a KTP is 7.4 days. The cost is not much different in each region; it is around Rp. 19,000. The use of informal intermediaries is common to obtain ID cards: $47 \%$ of households use their services;

4) Only $15 \%$ of households have access to information about village budget allocations and $25 \%$ of households have access to information on village development programs;

5) Approximately half of households states that the level of participation in village activities do not differ from previous years, while a third of households feels that their participation has increased. The rest, around $10 \%$ of households states that their participation declines. The number does not differ among the regions.

6) Participation in general elections is very high: $94 \%$ of households has recently participated in the elections. However, only $44 \%$ of households participating in the election know the background of the candidates.

7) An important indicator of governance besides transparency is the extent of corruption cases. Very few people admit that corruption and bribery have occurred in various public service institutions. Knowledge of bribery cases is said to occur most often in police, where $19 \%$ of households state they know about the incident. Educational institutions are not free from illegal transactions. As many as $9 \%$ of households are aware of corruption and / or bribery that occur in educational institutions;

8) The community identifies five main aspects of health services that need improvement: availability of medicines and vaccines (24\%), affordability of medical services $(20 \%)$, physical condition of health service locations (19\%), attention and attitudes of medical officers $(15 \%)$, and the time of wait at each health service place $(7 \%)$. According to the head of the Community Health Center, their involvement in determining the rates of the Community Health Center is much lower than what is reported by the health department. 
The data shows that (1) decentralization and regional autonomy have not provided sufficiently strong expectations for good governance; (2) the division of regions and direct regional elections actually lead the problems of inheritance and transition to poverty in a number of regions; (3) poverty can only be eradicated by pioneering and giving serious attention to good governance. Several provinces in Indonesia have become a separate lesson where good governance prioritizes budgets and accesses better public services to local people. The JKI database under the leadership of Ahok can become a model for how to prioritize public budgets for the benefit of the poor through improving public facilities access to public services and scholarships to the poor.

\section{Conclusion}

Governance and poverty are closely related. Crisis in the governance does not only characterize and mark areas with very high poverty but also becomes a road map of how the region is led and controlled by corrupt governments. It does not only close the access to the wider community to utilize the APBD to achieve prosperity but also reduces the use of public budgets (APBD) in carrying out programs for the poor, such as access to education, health, basic infrastructure, drinking water, electricity and so on. Regions with high poverty ratings have the same general symptoms such as; (1) more money is spent on bureaucratic spending; (2) basic infrastructure for roads with holes that are not asphalted and the like; (3) limited fulfillment of community needs for electricity, clean water, and so on; (4) the community has limited access to government public services; (5) governance requires expensive and inefficient (wasteful) costs.

For this reason, there are several things that need to be done as recommendations for changes in government policies;

1) The government needs to strengthen the institutions of political parties - encourage regeneration and recruitment in more open political parties, so as to produce more qualified regional leaders;

2) Cutting the authority chain that limits the coordination between the central government and the regional government by holding regular and scheduled coordination between the central government and regional governments;

3) Giving direction to local governments to use a huge part of the regional budget for the public interest, especially prioritizing the poor;

4) Make a road map or a measurable and planned development road map for regions that are continually ranked as the poorest ones - for those regions, the government also needs to provide space for the expansion of local community participation in the governance of the local government;

5) Opening the space for the emergence of local democratic inclusion based on rights and justice for the community - through policies that benefit the community in obtaining rights and justice in the governance of local government;

6) Decentralization in the form of improvement and local democracy needs to be actualized in the limitations of its success for certain regions and the limitations of its activities for regions that have suffered a setback.

It is believed that the future of Indonesia under decentralization and simultaneous local elections will get better, at least the governance is controlled by visionary leaders who are competitive and committed to eradicating poverty. 


\section{References}

[1] W. R. Jati, "Inkonsistensi paradigma otonomi daerah di Indonesia: Dilema sentralisasi atau desentralisasi," J. Konstitusi, vol. 9, no. 4, pp. 743-770, 2016.

[2] E. Suaib and W. Syifatu, "Desentralisasi dan Oligarki Predator di Wakatobi: Peran Oligarki dan Elit Penentu dalam Pembangunan Perdesaan," J. Penelit. Polit., vol. 13, no. 2, pp. 167-191, 2016.

[3] C. Jackop, A Crisis of Governance: Zimbawe. USA: Algora Publishing, 2004.

[4] A. Fung and E. Olin Wright, Deepening Democracy. London-New York: Verso, 2003.

[5] Alonso-Terne Rosa, "Does Corruption AffectIncome Inequality and Poverty," Int. Monet. Fund, Washington, DC. IMF Work. Pap., vol. 98, no. 76, 1998.

[6] Sudarsono, "Governance and Poverty Reduction: Evidence from Newly Decentralized Indonesia," Smeru Work. Pap. Smeru Inst., 2004. 